\title{
SISTEM PAKAR DIAGNOSA PENYAKIT BAYI DAN BALITA BERBASIS ANDROID DENGAN MENGGUNAKAN ALGORITMA DEPTH FIRST SEARCH
}

\author{
Muhammad Syaifuddin, Anton Setiawan Honggowibowo \\ Jurusan Teknik Informatika \\ Sekolah Tinggi Teknologi Adisutjipto Yogyakarta \\ informatika@stta.ac.id
}

\begin{abstract}
It is a must for children (infants and toddlers) to get more attention due to their health because their body's protections are not yet strong. This makes them susceptible for germs, bacteria, and viruses attacks. Those attacks cause disease. This disease symptom could appear all of sudden to the children. It makes their parents afraid, especially for those who have less sensitiveness for the symptom. For this reason, I make an application based on android smartphone expert system to provide information on type of disease, treatment, and prevention based on the symptoms given. This application uses forward chaining and backward chaining inference engine to make conclusion, and Depth First Search algorithms for searching the method. The result shows that this application could help parents in giving some information about common diseases attacked to infants and toddlers. This application facilitates them in delivering information which can be accessed anywhere as first aid for infants and toddlers who indicated disease.
\end{abstract}

Keywords: Expert System, Infants and toddlers diseases, Android, Depth First Search.

\section{Pendahuluan}

Anak (bayi dan balita) perlu diperhatikan kesehatannya dikarenakan lemahnya ketahanan tubuh membuat bayi dan balita sangat rentan terhadap kuman, bakteri dan penyakit. Sering kali anak mengalami kesulitan dalam menjelaskan keluhannya, oleh karena itu orang tua diharapkan dapat menangkap setiap bahasa tubuh dari anak mereka. Pada umumnya, apabila anak mengalami gangguan kesehatan maka orang tua akan memeriksakan kesehatan anaknya ke tempat pelayanan kesehatan dan berkonsultasi dengan tenaga kesehatan yang ahli dalam bidangnya, tetapi terkadang terdapat hambatan seperti terbatasnya jam kerja (praktek). Dengan adanya hambatan tersebut maka dibutuhkan sebuah aplikasi sistem pakar yang dapat membantu orang tua dalam mengenali gejala-gejala suatu penyakit dan menarik kesimpulan dari sejumlah fakta yang ada, sehingga orang tua segera dapat melakukan pertolongan pada anak mereka.

\section{Kajian Pustaka}

Aplikasi Sistem Pakar Untuk Mendiagnosa Penyakit pada Bayi Menggunakan Piranti Mobile oleh Sulastri dan Eri Zuliarso Fakultas Teknologi Informasi Universitas Stikubank Semarang.

Sistem Pakar Mendiagnosa Penyakit Umum yang Sering diderita Balita Berbasis Web Di Dinas Kesehatan Kota Bandung dengan Menggunakan Metode Depth-First Traversal oleh Tati 
Harihayati dan Luthfi Kurnia Fakultas Teknik dan Ilmu Komputer Universitas Komputer Indonesia.

Analisis Perbandingan Breadth-First Search dan Depth-First Search pada Aplikasi Sistem Pakar Pengobatan Tradisional oleh Ifrisima Teknik Informatika Sekolah Tinggi Teknologi Adisutjipto.

\section{Metodologi Penelitian}

\subsection{Sistem Pakar}

Secara umum, sistem pakar (expert system) adalah sistem yang berusaha mengadopsi pengetahuan manusia ke komputer, agar komputer dapat menyelesaikan masalah seperti yang biasa dilakukan oleh para ahli. Sistem pakar yang baik dirancang agar dapat menyelesaikan suatu permasalahan tertentu dengan meniru kerja dari para ahli. Dengan sistem pakar ini, orang awampun dapat menyelesaikan masalah yang cukup rumit yang sebenarnya hanya dapat diselesaikan dengan bantuan para ahli. Bagi para ahli, sistem pakar ini juga akan membantu aktivitasnya sebagai asisten yang berpengalaman.

\subsection{Metode Pencarian Algoritma Depth First Search (DFS)}

Pada metode Depth First Search, proses pencarian dilakukan pada semua anaknya sebelum dilakukan pencarian ke node-node yang selevel. Pencarian dimulai dari node akar ke level yang lebih tinggi, proses diulangi terus hingga ditemukan solusi, jika telah menemukan solusi maka pencarian Depth First Search akan berhenti, meskipun masih ada solusi lainnya.

\subsection{Perancangan Perangkat Lunak}

Software atau perangkat lunak merupakan program komputer yang berfungsi sebagai sarana interaksi (penghubung) antara pengguna (user) dan perangkat keras (hardware). Berikut ini adalah beberapa kebutuhan perangkat lunak yang digunakan dalam pembuatan aplikasi, yaitu:

1. Sistem operasi Microsoft Windows 832 bit sebagai sistem operasi laptop.

2. Jdk-7u51-windows-i586 sebagai java compiler berbasis windows.

3. IDE Eclipse sebagai editor bahasa pemrograman java.

4. Android SDK dan ADT Tools

5. Database SQLite sebagai local database pada smartphone android.

6. Sistem operasi android versi 3.0.4 (Ice Cream Sandwich) dan versi-versi lain di atasnya sebagai sistem operasi pada smartphone android.

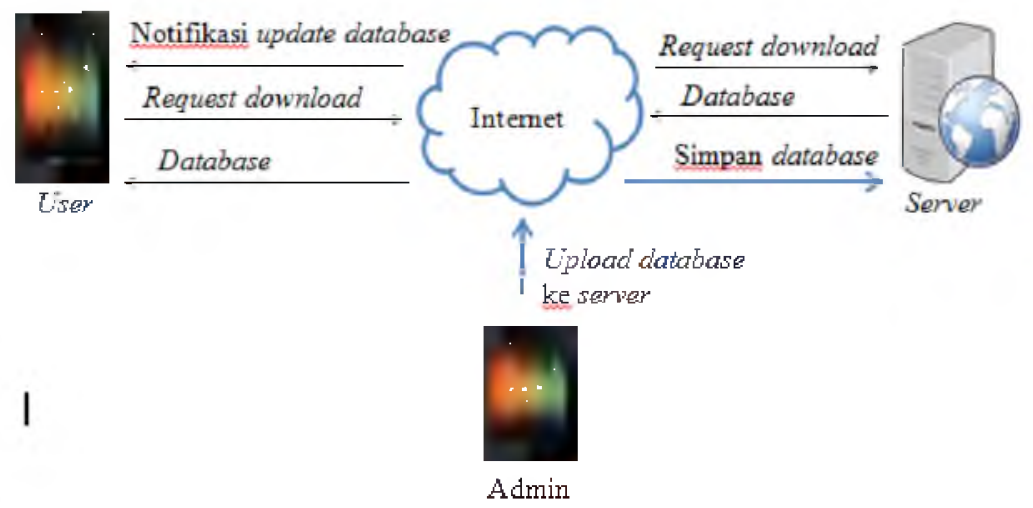

Gambar 1 Infrastruktur jaringan aplikasi 


\section{Hasil Dan Pembahasan}

\subsection{Aplikasi Admin}

Aplikasi admin adalah aplikasi yang digunakan oleh admin untuk melakukan penginputan data basis pengetahuan pada aplikasi sistem pakar, dapat dilihat pada gambar 2 dan 3.

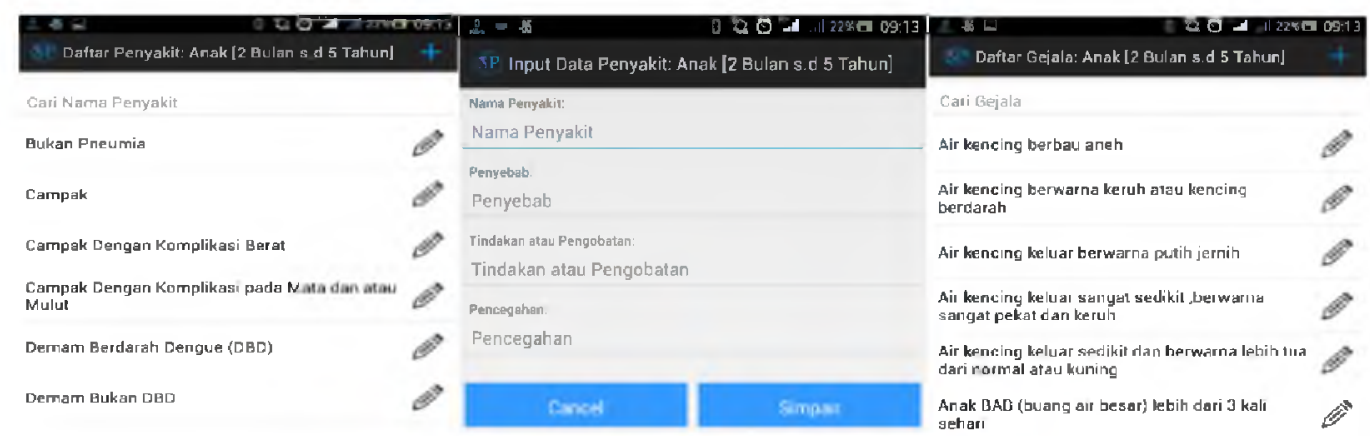

Gambar 2 Tampilan daftar, input data dan tampilan gejala penyakit

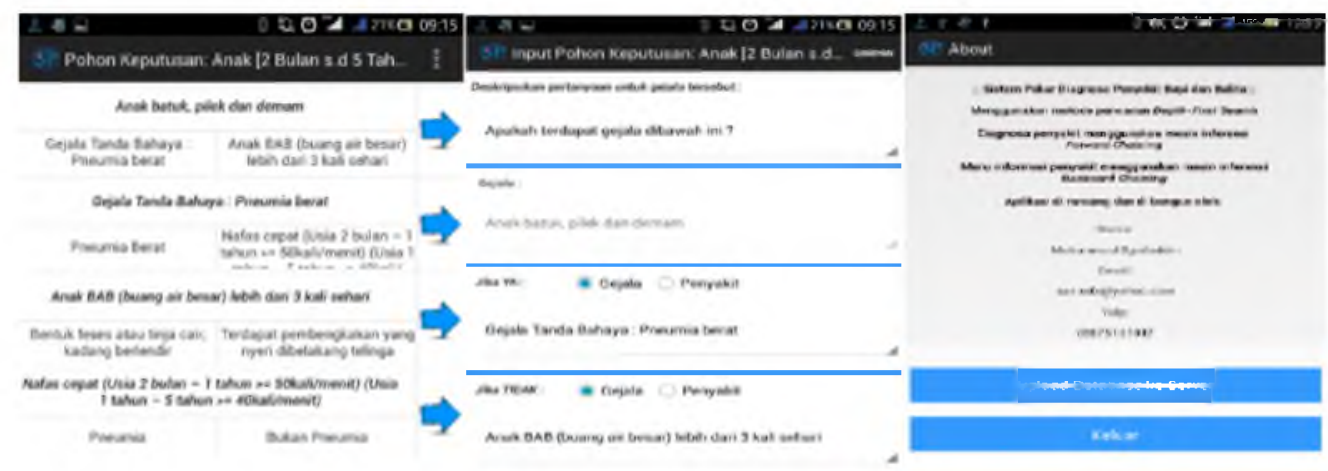

Gambar 3 Pohon dan input keputusan, serta upload data ke server

\subsection{Aplikasi User}

Aplikasi user adalah aplikasi yang digunakan oleh user untuk melakukan diagnosa penyakit, dapat dilihat pada gambar 4 .
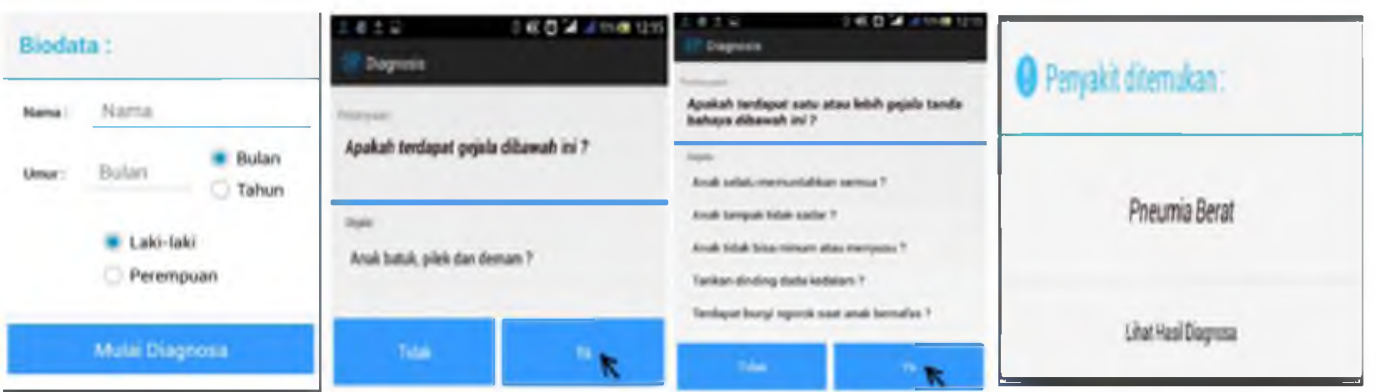

Gambar 4 Mengisi bisodata, pohon diagnosa pertama, pertanyaan dan gejala node kedua pada nilai 'Ya' dan hasil diagnosa

\subsection{Analisis Smartphone Android}

Hasil uji coba aplikasi pada smartphone andorid Lenovo P780 dapat dilihat pada Tabel 1 dan hasil uji coba aplikasi pada smartphone andorid Samsung Galaxy Tab P7500 dapat dilihat pada Tabel 2. 
Tabel 1 Tabel uji coba aplikasi pada smartphone android Lenovo P780

\begin{tabular}{|c|c|c|c|}
\hline No & Sistem operasi & Aplikasi user & Aplikasi admin \\
\hline 1 & $\begin{array}{c}\text { Android 4.2.2 } \\
\text { (Jelly Bean) }\end{array}$ & $\begin{array}{l}\text { 1. Install Aplikasi } \\
\text { 2. Melakukan } \\
\text { diagnosa penyakit } \\
\text { 3. Download database }\end{array}$ & $\begin{array}{l}\text { 1. Install aplikasi } \\
\text { 2. Melakukan input data } \\
\text { 3. Upload database ke } \\
\text { server }\end{array}$ \\
\hline 2 & $\begin{array}{c}\text { Android } 4.4 .2 \\
(\text { KitKat })\end{array}$ & $\begin{array}{l}\text { 1. Install Aplikasi } \\
\text { 2. Melakukan } \\
\text { diagnosa penyakit } \\
\text { 3. Download database }\end{array}$ & $\begin{array}{l}\text { 1. Install aplikasi } \\
\text { 2. Melakukan input data } \\
\text { 3. Upload database ke } \\
\text { server }\end{array}$ \\
\hline
\end{tabular}

Tabel 2 Tabel uji coba aplikasi pada smartphone android Samsung Galaxy Tab P7500

\begin{tabular}{|c|c|c|c|}
\hline 0 & $\begin{array}{l}\text { Sistem } \\
\text { operasi }\end{array}$ & Aplikasi user & Aplikasi admin \\
\hline & $\begin{array}{l}\text { Android } \\
4.0 .4 \\
\text { (Ice Cream } \\
\text { Sandwich) }\end{array}$ & $\begin{array}{l}\text { 1. Install Aplikasi } \\
\text { 2. Melakukan } \\
\text { diagnosa } \\
\text { penyakit } \\
\text { 3. Download } \\
\text { database }\end{array}$ & $\begin{array}{l}\text { 1. Install aplikasi } \\
\text { 2. Melakukan input } \\
\text { data } \\
\text { 3. Upload database ke } \\
\text { server }\end{array}$ \\
\hline
\end{tabular}

\subsection{Analisis Hasil Uji Coba Pengguna}

Pengujian dilakukan dengan mengajukan kuesioner kepada pakar yaitu tenaga kesehatan (dokter anak) yang berjumlah 30 orang. Adapun pertanyaan-pertanyaan yang diajukan ke responden sebagai berikut :

1. Aplikasi diagnosa penyakit bayi dan balita yang dibangun telah menampilkan dan menghasilkan hasil olahan data yang sesuai. (Hasil jawaban pertanyaan 1, dapat dilihat pada Tabel 3)

2. Anda puas atas hasil aplikasi diagnosa penyakit bayi dan balita berbasis android (Tingkat kepuasan pengguna yaitu hasil jawaban pertanyaan 2, dapat dilihat pada Tabel 4)

Tabel 3 Tabel hasil kuesioner pakar pertanyaan 1

\begin{tabular}{|c|c|c|c|}
\hline Keterangan & $\begin{array}{l}\text { Skor Likert } \\
\text { (Pn) }\end{array}$ & Ahli pakar & Skor (Rs) \\
\hline Sangat Setuju (SS) & 5 & 10 & 50 \\
\hline Setuju (S) & 4 & 12 & 48 \\
\hline Cukup Setuju (S) & 3 & 8 & 24 \\
\hline Tidak Setuju (TS) & 2 & - & - \\
\hline Sangat Tidak Setuju (STS) & 1 & - & - \\
\hline \multicolumn{2}{|l|}{ Jumlah } & $\mathrm{T}=30$ & Ts $=122$ \\
\hline
\end{tabular}


Dari hasil analisa pada Tabel 3 dilakukan perhitungan dengan menggunakan skala Likert, yaitu:

$$
\begin{aligned}
& I K K=\frac{T s}{Y} \times 100 \% \\
& =\frac{122}{150} \times 100 \\
& =81.3 \%, \text { kategori sangat setuju. }
\end{aligned}
$$

Tabel 5 Tabel hasil kuesioner pakar pertanyaan 2

\begin{tabular}{|l|l|l|}
\hline Keterangan & Responden & Persentase (\%) \\
\hline Sangat Setuju (SS) & 10 & $33.3 \%$ \\
\hline Setuju (S) & 12 & $40 \%$ \\
\hline Cukup Setuju (S) & 8 & $26.7 \%$ \\
\hline Tidak Setuju (TS) & - & - \\
\hline Sangat Tidak Setuju (STS) & - & - \\
\hline
\end{tabular}

\section{Penutup}

\subsection{Kesimpulan}

Dari hasil uji coba dan yang dilakukan dapat ditarik kesimpulan, aplikasi sistem pakar diagnosa penyakit bayi dan balita berbasis android dengan menggunakan algoritma Depth First Search yaitu:

1. Aplikasi sistem pakar yang dibangun dapat mempermudah orang tua dalam memberikan informasi mengenai suatu penyakit dan gejala-gejalanya.

2. Aplikasi sistem pakar yang dibangun dapat memberikan informasi mengenai tindakan atau pengobatan dari setiap penyakit yang berhasil didiagnosa.

3. Aplikasi sistem pakar yang dibangun telah dapat menggunakan menggunakan mesin inferensi forward chaining dan backward chaining dalam melakukan penarikan kesimpulan, dan menggunakan algoritma Depth First Search sebagai metode pencariannya.

4. Dari hasil uji skala Lickert, sebesar $81.3 \%$ masuk kategori sangat setuju, maka dapat disimpulkan bahwa aplikasi sistem pakar yang dibangun sudah sesuai dengan tujuannya yaitu dapat melakukan diagnosa penyakit, memberikan informasi tentang suatu penyakit beserta gejalanya dan menampilkan olahan data yang sesuai.

5. Jumlah responden yang setuju puas atas hasil aplikasi diagnosa penyakit bayi dan balita sebebar $40 \%$, sedangkan jumlah responden yang sangat setuju sebesar $33.3 \%$ dan jumlah responden yang cukup setuju sebesar $26.7 \%$.

\subsection{Saran}

Aplikasi sistem pakar diagnosa penyakit berbasis mobile smartphone sebaiknya lebih banyak dikembangkan untuk hewan, tumbuhan, usia dewasa, dan usia lanjut. 


\section{Daftar Pustaka}

Arhami, Muhammad. 2005. Konsep Dasar Sistem Pakar. Yogakarta: Andi.

Arikunto, Suharsimi. 2010. Prosedur Penelitian: Suatu Pendekatan Praktik (Edisi Revisi 2010). Jakarta: Rineka Cipta.

Harihayati Tati, Kurnia Luthfi. 2012. Sistem Pakar Mendiagnosa Penyakit Umum Yang Sering Diderita Balita Berbasis Web Di Dinas Kesehatan Kota Bandung. Jurnal Komputer dan Informatika (KOMPUTA) Edisi. I Volume. 1, Maret 2012. Bandung: Universitas Komputer Indonesia.

Ifrisima. 2013. Analisis Perbandingan Breadth-First Search Dan Depth-First Search Pada Aplikasi Sistem Pakar Pengobatan Tradisional. Jurnal Adisutjipto Informatics Society (COMPILER) Volume 2, Nomor 2, November 2013. Yogyakarta: Sekolah Tinggi Teknologi Adisutjipto.

Sulastri, Zuliarso Eri. 2011. Aplikasi Sistem Pakar Untuk Mendiagnosa Penyakit Pada Bayi Menggunakan Piranti Mobile. Jurnal Teknologi Informasi DINAMIK Volume 16, No.1, Januari 2011: 1-13. Semarang: Universitas Stikubank Semarang.

Kusumadewi, Sri. 2003. Artificial Intelligence (Teknik dan Aplikasinya). Yogyakarta: Graha Ilmu. 